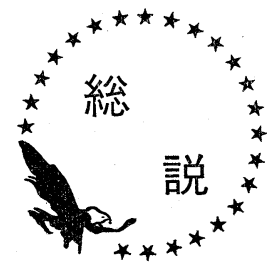

1.はしがき

近年, 工業用燃焼装置は高負荷化, 高性能化が促進 されてきたが，ごく最近はこれらの経済性や性能向上 に対する要求以上に，大気污染の防止とともに騒音の 減少対策が社会問題として大きくとりあげられるょう になつてきた。

一般に工業用燃焼装置における騒音発生源として は，送風機，ポンプ，モータなどの補機類あるいは被 熱物送り装置などの騒音源も含まれるが，ここでは， ボイラや加熱炉などの連続燃燒装置における燃焼にと もなつて発生する騒音に限定し，その発生の原因，防 止方法について述べ。

\section{2. 燃焼騒音と振動燃焼}

\section{2-1 燃焼騷音}

気体中の圧力変動は音波として伝播するが，気体が 燃焼反応などにより熱量を授受すると温度変化に影響 を与え, 压力変動をさらに増加させる。したがつて単 なる流体騒音に付加した燃焼騒音が発生する。

燃焼騒音は，乱流火炎の発生に基づく乱流燃焼騒音 と, 気体流路系との共振による振動燃焼騒音に分けら れる。

2-1-1 乱流燃焼騒音

流れが層流の状態で燃焼する場合は層流燃焼，乱流 の場合は乱流燃焼といわれている。層流燃㟐では火炎 形成に伴う火炎騒音は発生しないといわれているが, 乱流燃燒ではその乱れのために火炎発生による騒音が 発生する。しかし実際の然焼状態では，噴流騒音など の流体騒音を伴うので，火炎騒音と流体騒音を区別す ることは困難である。

なお, 乱流燃焼騒音は, 㓪・暖房用燃焼器具などの 開放大気中で燃焼する場合に問題となる。

2-1-2 振動燃燒騒音

ボイラや加熱炉などの工業用燃焼装置では，大部分 のものが空間的に固体壁で制限された燃焼室内で燃焼 するが，騒音が問題とされる場合は，多くの場合振動
燃焼によつて発生する共鳴音と考えられる。

一般に振動燃焼による騒音は, 乱流火炎騒音に比へ てその音の強さはきわめて強く, プラント全体の騒音 最高值に影響を与える。したがつて工業用燃焼装置の 騒音を問題とするには，振動燃焼騒音を議論しなくて はならない。

\section{$2-2$ 振動燃焼}

\section{2-2-1 振動燃焼の分類}

振動燃焼は燃焼によつて振動が励起される現象であ るが，これを大別すると音響共鳴振動燃焼と非音響的 共鳴振動燃焼に分けられるが，一般に燃焼負荷率の大 きい燃焼装置ほどはげしい振動燃燒を生ずる。

（1）音響共鳴振動燃焼

燃焼室を含屯気体流路系の音響的固有振動が燃焼に よる発熱により励振される現象であり，振動燃燒の振 動数は燃焼室系統の音響共鳴振動数に近い。音響共鳴 振動燃焼をさらに細分化すると，燃焼室内に圧力波の 分布が存在する気柱振動燃焼と，压力波の分布がなく 燃焼室内の圧刀が一様に変動する体積振動燃焼に分け ることができる。

a ) 気柱振動燃焼

振動の波長が燃焼室寸法に比へて同程度かあるいは 小さい場合には，燃焼室に圧力波の分布が生ずる。こ の場合，振動数が燃焼室系の軸方向の音響共鳴振動数 に近い場合は，軸方向モードの振動燃焼といえる。ま た振動数が半径方向の音響共鳴振動数に近い場合は, 半径方向モードの振動燃焼といえる。

普通の工業用燃焼装置では, 軸方向モードの振動燃 焼が問題となる。熱風炉，ラジアントチューブなどの 振動然燒はこの形態のものである。

b ) 体積振動燃焼

振動による波長が燃焼室寸法に比べて十分大きく, 燃焼室系が絞り部と容積タンクとからなる仮想のヘル ムホルツ共鳴器の共鳴振動数が基準の振動となる場合 の振動燃焼で，燃焼室は単なる音響的空どうと考える 
ことができ，振動による各変動量は燃燒室内で一様に 分布しているものと考えられる。

このような振動燃焼は, 温水ポイラなどで発生す る。

（2）非音響的振動燃焼（脈動燃焼）

発振条件が燃焼条件や燃料系統の構成などによつて 定まる振動燃焼で, 普通周波数は低い。この種の振動 燃焼では騒音より火炎の吹き消えが問題とされる場合 が多い。

なお, 振動燃焼の分類の方法として, 普通振動数の 範团によつて高周波振動燃焼，中間周波振動燃焼，低 周波振動燃焼などに分けられている。これはロケット について試みられた分類法で半径方向モードの振動を 高周波振動, 軸方向モードでかつ振動数が音響共鳴振 動数に近、場合を中間周波振動，振動数が音響共鳴振 動とほとんぞ関係なく振動数が前二者に比へて比較的 近い場合を低周波振動之分けているが，一般の燃焼装 置に至るまで周波数によつて分類するのは適当でない と考える。たとえば軸方向モードの音響共鳴振動をと りあげて考えてみると，熱風炉のように燃焼室の長さ が数十西におよぶ場合は基本振動数は数サイクル程度 にすぎない。すなわち同じ振動形態でも周波数は燃焼 室の寸法によつて定まるので，相対的な表現として高 周波振動ともいえ, あるいはまた低周波振動ともいえ る。

2-2-2 振動燃焼の発生原因

音響共鳴振動燃焼が発生するためには，燃焼による 発熱反応と共鳴するための気体流路系が存在し, それ がフィード バック機構により結合する必要がある が，振動燃焼を持続させるためのエネルギーを与える のは, 燃焼率の変動による発熱量変動に基づくもの で, これが振動燃燒の起振力となる。

しかし，燃焼率の变動機構は，燃焼条件，バーナあ るいは燃料・空気供給系などの構成により種々異なる ものと考えられるが, 現在, ほとんど明確にされてい ない。

推定される燃焼率の変動機構を若干あげてみると，

(1) 燃焼室内の圧力变動の影響をうけて燃焼用空気 流が変動し, 燃料と空気の局所混合比が 変動す る。

(2) 燃料ガス噴出圧力の低いガスバーナでは，燃焼 室内の圧力変動の影響をうけて, 燃料ガスの噴出 流量が変動し, 燃燒室内への発熱入力量の変動が 付吅わる。

(3) 噴霧燃焼の場合は, 図 1 に示すように油滴と周

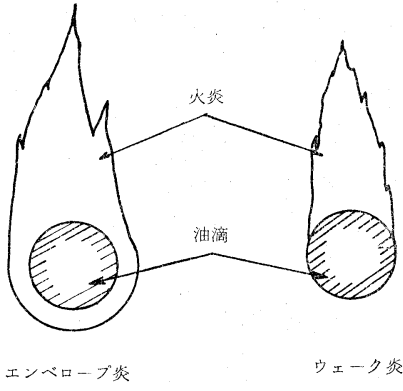

図 1 油滴における火災

囲ガス流の相対速度の变動の影響をうけ，一部の 油滴が，ウェーク炎からエンベロープ炎に，ある いはその逆に遷移することがある。一般にウェー ク炎は燃焼率が小さく，エンベロープ炎では燃焼 率が大きいので，遷移によつて燃焼率の変動が生 ずる。

(4) 火炎の保持が不安定な場合に着火位置が変動す ることがあり，局部的な燃焼率の変動が生ずる。 以上の上うに, 燃焼率の変動の要因はそれぞれ単独 のものが振動燃焼の起振力となることもあるが，いく つもの要因が組合わさつて複雑な変動機構を構成する 場合もあり，振動燃焼が発生する場合は，個及の場合 についての原因を推定しなければならない。

2-2-3 振動燃燒の防止方法

振動燃焼を防止するには，まずその振動数，振幅を しらべ，振動の形態を明らかにするとともに，できる 限り発熱率変動機構を明確にすることが望ましい。

すなわち，防止方法として，バーナに関係する対策 とバーナに関係しない対策とに大別することができる が，発生している振動燃焼の具体的機構が明らかにさ れている方が，防止方法の基本的方針がたてやすい。

そこで，振動燃焼を防止する方法として，バーナに 関係する対策とバーナに関係しない対策に分けると， つぎのようになる。

(1) パーナに関係する対策

(1) 全体の流路系の振動モードを考虑し，バーナ取 付け位置が振動燃焼を発生しないような位置を選 ぶ。

たとえば，斉藤の研究1)によると，図 2 に示さ

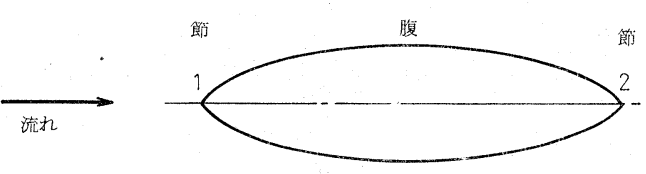

図 2 振動モード 
れるように，気体の流れの方向に対し加熱源は圧 力変動の節 1 から腹までの間にあるとその振動モ 一ドの励振源になりうるが，腹から節 2 の間にあ るときはその振動を抑制するようになる。冷却熱 源ではこれとちょう度対称になる。いずれの場合 でも，关の効果の大きさは節と腹の中央において 最大となる。

また佐藤らの研究 22 による, 燃焼領域が圧力 の腹と節との中心に位置するか，あるいは燃燒領 域のすぐ上流に圧力の腹が位置する場合に著しい 発振をするものとしている。

(2) 火炎安定化が不十分で, 着火開始位置が気流に よつて変動しやすい場合，火炎保持方法を改善し 火炎が変動しにくいようにする。

(3) バーナにおける風圧降下を大，すなわち空気流 速を速くして同じ風圧変動に対し風量変動量を少 なくし, 燃料と空気との局所混合比の変動などを 小さくする。

(4) 燃料が過濃あるいは希薄条件では一部の燃料に 発生している火炎が吹消えることがあり，流れが 変動する場合は着火，吹消えを振動的に繰返し振 動燃焼を発生する。このような場合, 空気流と燃 料流の混合パターンを変えることにより振動燃焼 を解決できることがある。

（2）バーナに関係しない対策

振動燃焼が発生する場合は, なるべく前述のバーナ の改善によつて防止するのが本筋であるが，いかなる 方法でも解決できない場合はつぎのような抑制法を採 用せざるを得ない。

(1) 気柱振動が発生する場合, 共鳴器を取付ける。

(2) 気柱振動燃焼の場合, 流速変動の腹のところに 絞りをもうけるか，あるいは圧力変動の腹のとこ

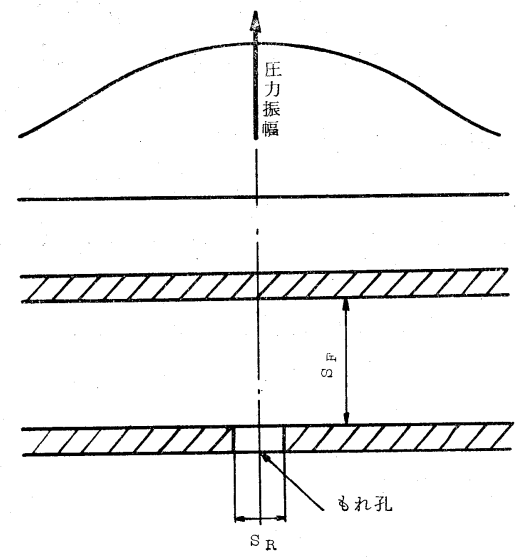

図 3 圧力変動の腹のところにもれをもうけた例
ろにもれをもうける。図 3 は圧力変動の腹のとこ ろにもれをもうけた場合の例で，著者らの実験結 果によると，もれ孔面積之燃焼室断面積の比が， $S_{R} / S_{F}=0.02$ の場合, 圧力振幅のもれがある場 合とない場合の比は $P^{\prime} / P=0.6$ になる。

(3) 圧力変動が腹であるところへ，逆にそこが節に なる性質をもつ管を接続する。

\section{3. 気柱振動燃焼による騒音}

実際のボイラや炉では，軸方向モードの気柱振動燃 焼による騒音がもっともよく問題となるので，本節で 例をあげながらさらに詳しく述べる。

\section{3-1 熱風炉の場合}

最近，高炉が大形化されるにともなつて，熱風炉も 大形化之高負荷燃焼が要求されているが，大部分の熱 風炉では，激しい振動燃焼を発生し，構造物の損賃が 生ずるとともに，激しい騒音が生ずるためにその対策 が問題になつている。

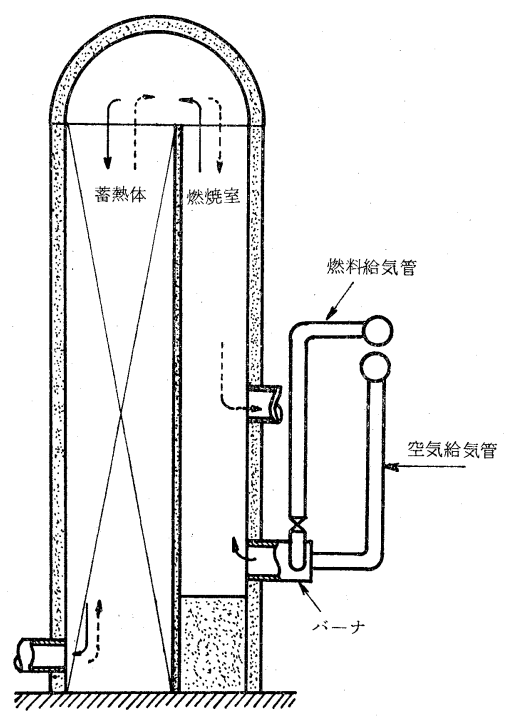

図4 カウパ-式熱風炉

図4はもつともよく用いられているカウパー式熱風 炉を示す。燃焼室は細長く気柱状になつており，バー ナは下端部にもうけられている。燃料としては普通高 炉ガスが用いられ，燃料噴出圧力，送風圧力は比較的 低い。

図 5 は，上記のような熱風炉で測定した各部の圧力 振幅の布分を示すが，圧力振幅の最大位置はバーナの すぐ上流部になり，給気管上流端と排気ドームで圧力 振幅はごく小さくなつている。すなわちこの燃焼流路 系をひとつの気柱とし両端が解放している場合の基本 

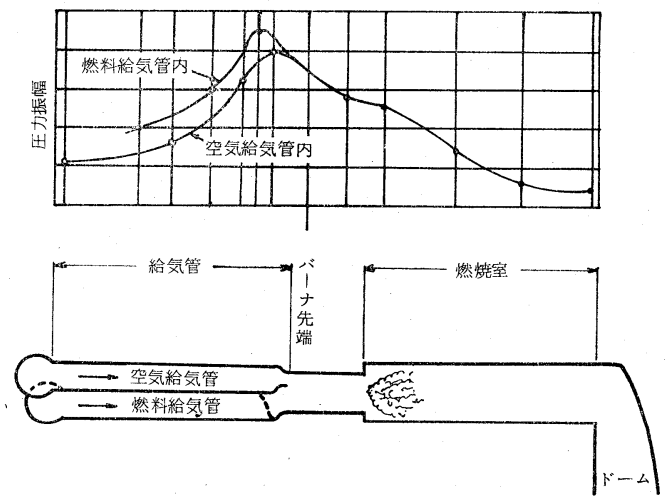

図 5 振動燃焼中の熱風炉における圧力振幅

振動モードを示している。この圧力振幅の分布とバー ナの位置関係は, 佐藤らの研究に基づく振動燃焼の発 振しやすい一つの状態であるといえる。

図 6 は，各部の圧力変動を測定した結果である。振 幅の時間に対する変化は比較的整つた正弦波である が, 基本振動数よりかなり近い脈動と周波数の高い高 次の振動をともなつていることがわかる。周波数のご く低い振動は音響共鳴振動に関係のない振動燃焼であ るものと考えられる。

この振動燃焼を抑制するため, まずバーナの改良を 試みたが，現場の制約もあり基本的に解決するのが困 難であるので，著者らはバーナの下流直後にへルムホ ルツ共鳴器を取付け圧力振幅をほぼ半隇させることに

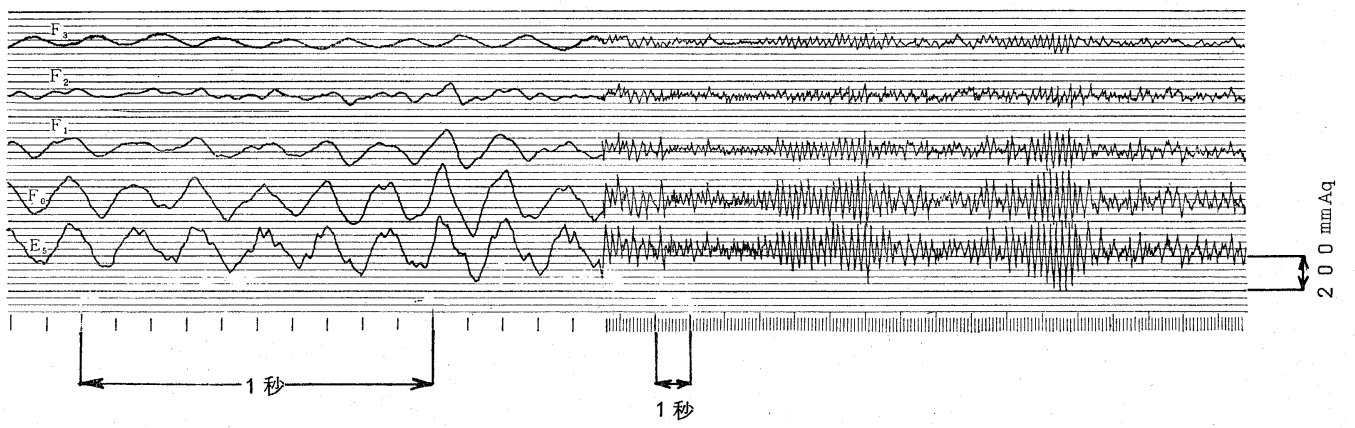

図 6 熱風炉における圧力変動の測定例

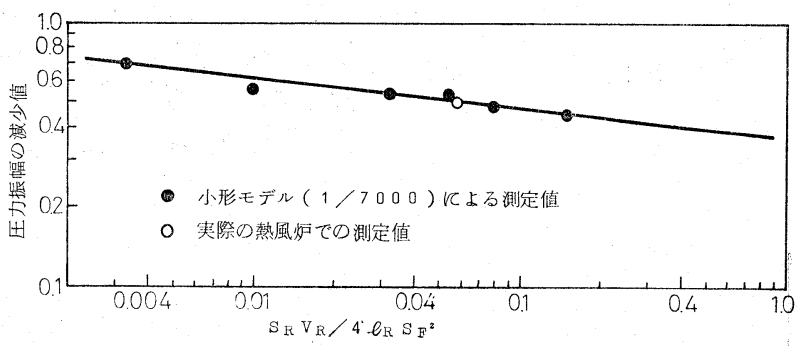

図7共鳴器の無次元パラメータと圧力振幅の減少比の関係

より，実用上振動燃焼を解決した3)。

図 7 は, 共鳴器の無次元パラメータ $S_{R} V_{R} / 4 l_{R} S_{F}{ }^{2}$ $\left(S_{R}:\right.$ レゾネータのスロート部断面積, $V_{R}:$ レゾネ 一夕体積, $l_{R}$ : レゾネータの長さ, $S_{F}$ : 熱風炉断面 積）に対し圧力振動の減少比の測定值を図示したもの である。黒丸印は燃焼量が約 $1 / 7,000$ 小形モデルに ついてしらべた実験值で，白丸印は実際の熱風炉で測 定した值であるが，寸法が大幅に異なつても圧力振幅 の減少比はかなりよく一致する。

3-2 昵筒煙管ボイラの場合
燃焼室寸法が約 $0.9 \phi \mathrm{m} \times 3 \mathrm{~m}$ の炉筒煙筒ボイラで, 図 8 に示すような新形回転バーナ4)を取付けて燃焼騒 音の発生状況を調べた結果を述べる。

この回転バーナは，図 9 に示すように液体燃料を微 粒化すると同時に噴萣群の状態で空気と均一混合する ことを考虑している。すなわち回転板の中心に向つて 噴出された液体燃料は回転板上で薄いフイルム状に延 ばされ，切欠のある回転板の緑を離れるとき微粒化さ れるが, 切欠の形状を適当に選べば半径方向の空気と 噴筩燃料との均一混合が期待できる。したがつて普通 


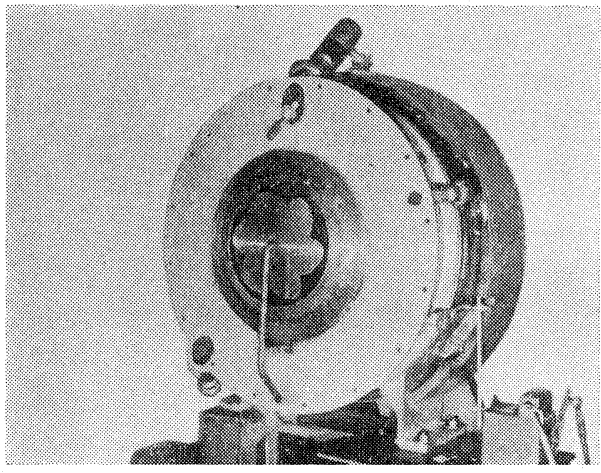

図 8 新形回転バーナ

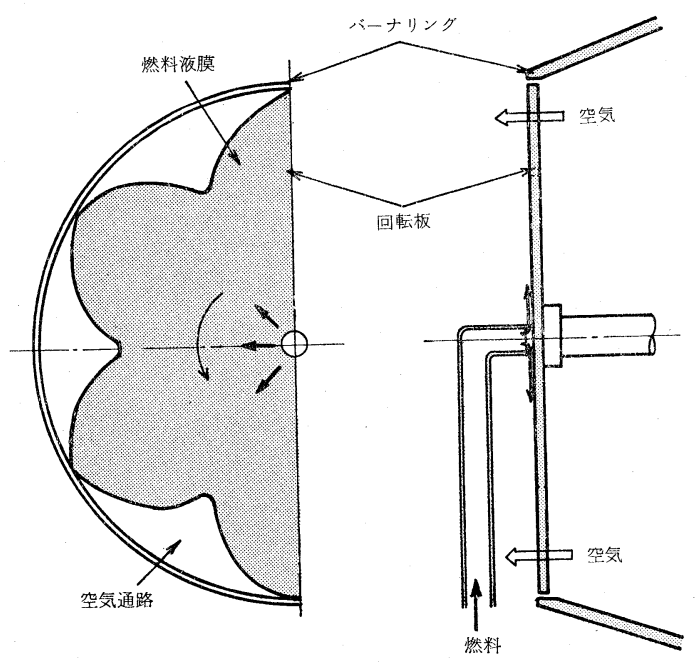

図 9 新形回転バーナの原理
のオイルバーナに比べて高負荷燃焼が可能である。開 発初期における燃焼時の周波数分析結果によると, $120 \mathrm{cps}$ 位に音压レベルの鋭い最大值があり，燃焼室の 長さ方向の音響共鳴振動数とほぼ一致しているので, 近似的に気柱振動燃焼として取扱えるものと考えられ た。図10は空気流量，燃料流量と共鳴音発生領域との 関係を示す。実線は原形バーナの共鳴音発生領域を示 すが，燃燒量が増加するにしたがい，空気過剩率が高 い範囲まで共鳴音が発生する。共鳴音の発生を解決す るため, ウィンドボックス内にガイドを取付け空気流 を内側方向に向け，噴霧のひろがり角を小さくなるよ うにした場合の共鳴音発生領域は点線で示されるが, 発生領域はかなり減少した。第 2 段階の解決策として スロート径を若干小さくすることによつて安全に共鳴 音の発生をなくすことができたが，結局，火炎の直径 を小さくし，燃焼率の高い領域を後流側にずらすこと により振動燃焼を解決できた実例の一つであるものと 考える。

\section{4. 体積振動燃焼による騒音}

体積振動然焼については従来あまりょく知られてい ないが，最近きびしい騒音対策規制により急に問題と されるようになつてきた温水ボイラの燃焼音が，この 種の振動燃焼に基づくものと考える。

4-1 従来の研究

Mauss ら ${ }^{5}$ は, 容量が30, 000kcal/hr 程度の温水ボ イラを図11のような単純化したモデルに置換え，体積 振動燃焼するものと考え, ヘルムホルツ共鳴振動数を 計算するとともに実験結果と比較している。図12は煙 突の長さを種々に変えた場合の振動数の計算結果およ

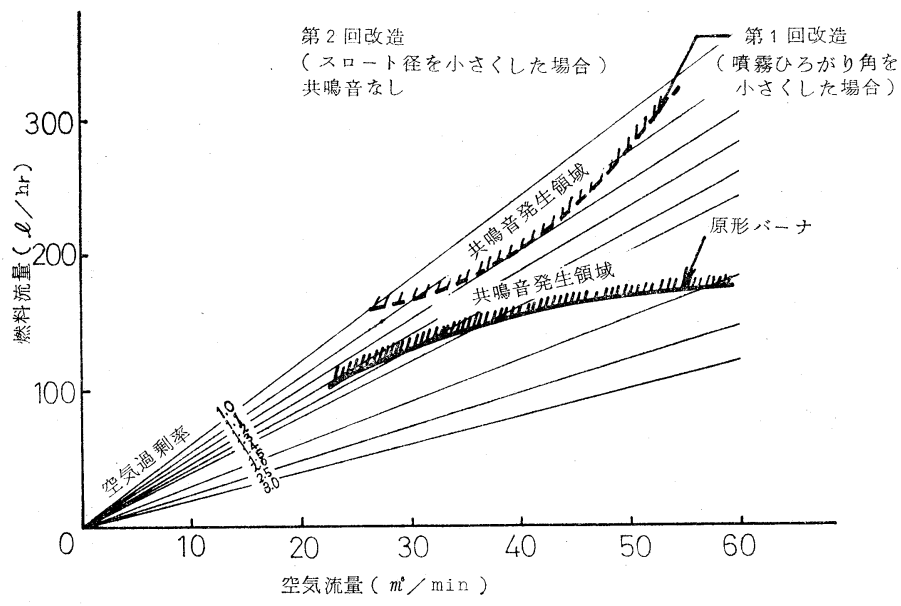

図10 共 鳴 音 の 発 生 領 域 


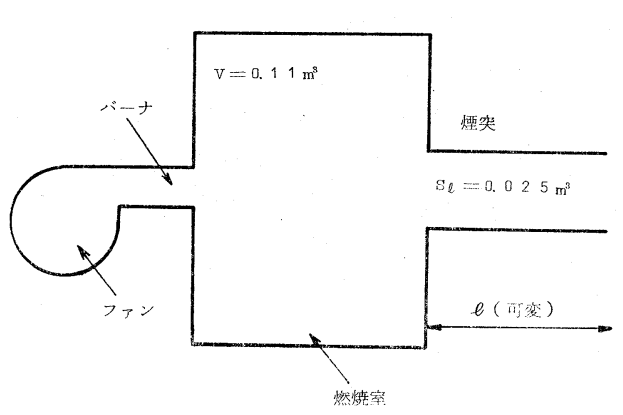

図11

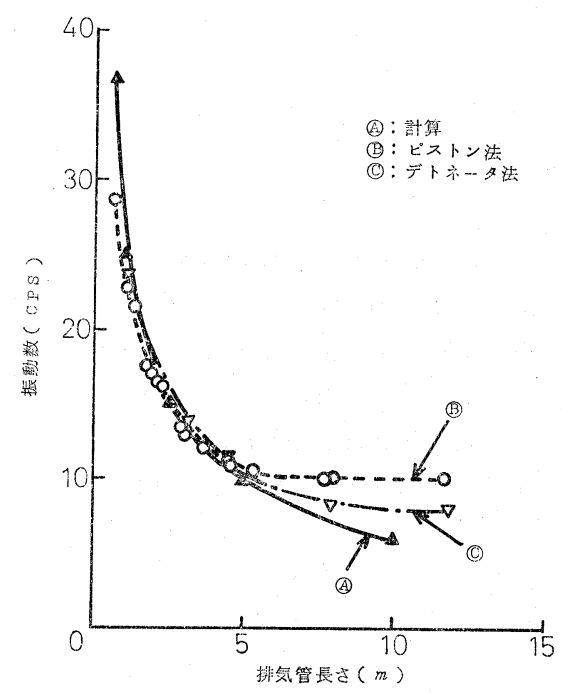

図12 周波数と排気管長さの関係

びピストン法，デトネータ法などによる実测值を示 寸。

佐藤ら ${ }^{6)}$ は，空気吸込口や煙道の長さがごく短いボ イラの火炉のモデルを図13のように考え，振動の波長 が火炉寸法に比へて十分大きい場合, 変動量の振幅や 位相は炉内に一様に分布しているものと考えた。すな

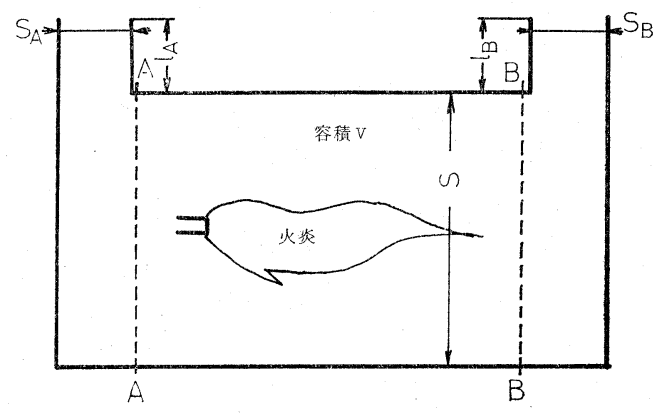

图13
わち炉内ガスの膨張には特有な方向性はなく，その膨 張量のみに注目し，炉内空間を音響的空洞，バーナ 部，排気部を絞り部とするへルムホルツ形の振動に帰 着するとしている。すなわち，式(1)で与えられる面 積 $S^{*}$ 長さ $l^{*}$ の絞り部と容積 $V$ のタンクからなる仮 想のヘルムホルツ共鳴器の共振振動数が基準の振動数 となる。

$$
\frac{S^{*}}{\rho l^{*}}=\frac{S_{A}}{\rho_{A} l_{A}}+\frac{S_{B}}{\rho_{B} l_{B}}
$$

\section{4-2 温水ボイラの場合}

図14は，燃焼室寸法が約 $0.5 \phi \mathrm{m} \times 0.5 \mathrm{~m}$ の温水ボイ ラでバーナを変えて振動数と音の強さの関係を実測し た一例を示すが，バーナを变えても $50 \mathrm{cps}$ 位で音圧レ ベルの最大值がある。従来発表されている温水ボイラ の測定結果によると, いずれもこの程度の低い周波数 で強い音が出るため騒音対策に苦慮されているが，燃 焼室寸法と周波数の関係を検討すると，気柱振動でな く体積振動燃焼による騒音であるものと考えられる。 なお，同じボイラでもバーナによつて音の強さが異な るのは，送風機の風圧〜風流特性あるいはレジス夕圧 損などの差により同じ風圧変動に対し風量変動量に差 異があるのが一つの原因になつているものと考える。

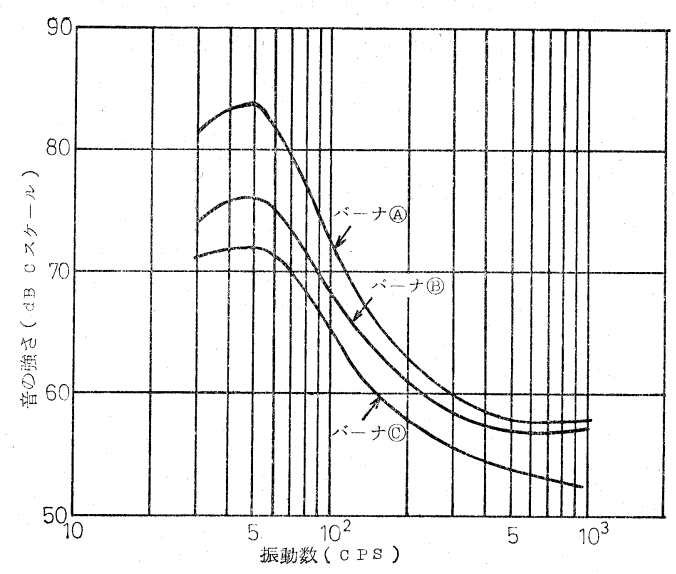

図14 温水ボイラの燃焼音の周波数特性の例

この種のボイラの騒音対策としては，ボイラ内に共 鳴器を取付け，圧力振幅を低減する方法と，火炎位置 が気流によつて変動しやすいガンタイプ・バーナの代 わりにウォール・フレーム・バーナの採用による解決 方法がある。

ただし，ウォール・フレーム・バーナは，火炎が変 動しにくい特長をもつているが，蒸発式であるため， 着火性能が悪く, また, 煙突のドラフト量の変動によ り, 空燃比が変動しやすく, ばいじん発生が多いの 
で, 今後の問題として振動燃焼を発生せず，しかも性 能のすぐれたバーナの開発が必要とされている。

$$
\text { 文献 }
$$

1) 斉藤，日本機械学会論文集，31，(221), 143(1965)

2）佐藤，鈴木，日本機械学会論文集，33，（252）, 1260 (1969)

3）辻，青木，森，石川島播磨技報，10，2（1970）
4) 辻 正一, 燃焼機器工学, 第 6 章, 日刊工業新聞 社 (1971)

5) F. Mauss, E. Perthurs \& B. Sale, 10th Symp. on Combustion, 1241 (1965)

6）佐藤, 鈴木, 三宮, 若園, 日本機械学会論文集, 36, (282), 266 (1970)

\title{
On Combustion Noise in Industrial Combustors
}

\author{
by Shōichi Tsuji \\ (Ishikawajima-Harima Heavy Industries Co., Ltd.)
}

SYNOOSIS : - Recently combustion noise problems in industrial combustors have been called into one of important problems together with air pollution problems.

Combustion noises are divided into the turbulent combustion noise and the oscillation combustion noise. In industrial combustrors such as boilers or heating furnaces, oscillation combustion noises are very more intensive than turblent combustion noises. Then this paper deals with the reasons of occurrence and the methods of prevention of oscillation combustion noises. 